\title{
UTILIZATION OF WHITE CEMENT IN CONCRETE MIX CONTAINING SRPC
}

\author{
[YASSER ABDEL GHANY FAWZY AND AHMED SHABAN ABDEL HAY]
}

\begin{abstract}
This paper discuss the effect of white cement on concrete properties such as fresh properties (slump), mass transport properties (Isat- sorptivity) and mechanical properties (compressive- splitting tensile). The thermal gravimetric analysis (TGA) of cement paste containing various blending of white cement with SRPC is also investigated. Concrete specimens were prepared with SRPC, water, sand and dolomite of $10 \mathrm{~mm}$ maximum nominal size. The blending of white cement with SRPC were $0,10,20,30,40,50$ and $100 \%$ at $w / c=0.50$. The effect of $10 \% \mathrm{SF}$ on compressive strength of concrete made with various percentage of white cement to SRPC is also considered. The results indicated that, $30 \%$ percentage of white cement to SRPC exhibited peak slump, the maximum compressive and splitting strength were observed at $30 \%$ percentage of white cement to SRPC .Also, the lowest values of Isat and sorptivity were occurred at $30 \%$ percentage of white cement to SRPC which agree with the results of compressive and splitting strength. $10 \%$ SF has an adverse effect on compressive strength of concrete containing various percentage of white cement.
\end{abstract}

Keywords - white cement-concrete-blending-SRPC-mass transport-compressive strength-silica fume.

\section{Introduction}

White cement is often used in architectural concrete, both precast and cast in place. Applications include precast curtain walls and facing panels, terrazzo surfaces, cement paint, tile grout and decorative concrete. White cement is a Portland cement typically made to conform to the specifications of ASTM C150 for Type I or Type III cements, but the manufacturing process is controlled so that the finished product is white in color. This is achieved by a careful selection of raw materials containing negligible amounts of iron oxide (not more than $0.5 \%$ by weight) and manganese oxide ; the substances that give cement its gray color (1).Suitable raw materials are chalks and lime stones having low iron contents and white iron- free clay $(2,3)$. White Portland cement produces more $\mathrm{Ca}(\mathrm{OH})_{2}$ in hydration, which results in alkalization and carbonization, color aging on the surface of colored Portland cement and concrete (4). Chandra and Jornstrom (5) studied the effect of types of cement on fluidity of mortar, he reported that no significant difference on the fluidity of mortars made with white cement or OPC up to $0.45 \mathrm{w} / \mathrm{c}$, whereas at $0.50 \mathrm{w} / \mathrm{c}$, the fluidity of white cement increased compared to OPC. The highest fluidity of white cement is attributed to the

\section{YASSER ABDEL GHANY FAWZY}

Faculty of Engineering, Beni-Suef University

Egypt

AHMED SHABAN ABDEL HAY

Faculty of Engineering, Beni-Suef University Egypt lower $\mathrm{C}_{3} \mathrm{~A}+\mathrm{C}_{4} \mathrm{AF}$ and alkali content and higher $\mathrm{SO}_{3}$. Hamad (6) studied the influence of cement type on slump and setting time, he indicated that, greater slump and shorter times of initial and final setting of mixes prepared with white cement compared to OPC. Hamad (6) also investigated the impact of white cement on compressive and splitting tensile strength of concrete, he reported that greater compressive strength of white cement compared to OPC, while the splitting tensile strength of gray cement was slightly greater than that of white cement. Lubeck et al (7) discussed the effect of $50 \%$ and $70 \%$ slag by mass of white cement and gray cement on compressive strength of concrete, they concluded that, the mixtures with $100 \%$ WPC showed higher compressive strength than those with $100 \%$ grey Portland cement up to an age of 28 days. At 91 days, the compressive strength values were similar.The strength of concrete made with white cement mixtures increased more quickly than that of concrete containing grey cement. At 7 days the strength of white cement was between $63 \%$ and $85 \%$ of the strength observed at 91 days, while the strength of grey cement mixtures was between $54 \%$ and $72 \%$ of strength at 91 days. As the percentage of slag in the mixture increased, the compressive strength decreased for white and OPC. The results agree with the results reported by (8-11). Petkova et al (12) reported that neat white cement is characterized by loss of mass below 5\%, a part of which due to dehydration of both crystal water and structural water from the decomposition of C-H and C-S-H , and the other to the de-carbonization of calcite.

Escalante and Sharp (13) reported that Portland cement is a poly- phase material containing silicates ( alite and belite), aluminate, ferrites and sulfates, whose hydration is complex and difficult to study due to the many factors involved. Some are intrinsic to the cement itself, such as its composition and fineness or specific surface. While others are related to hydration conditions, including w/c, absence or presence of admixtures. It is noted that most of the study on white cement in concrete has been focused on the hydration of neat white cement, effect of it on fresh, mechanical properties of concrete and impact of slag on efficiency of white cement. This study focused on the benefits of white cement (higher fineness and higher compressive strength at 28 days, compared to SRPC) by blending it with SRPC by various ratios to reduce the cost, the effect of this blending on various properties of concrete (fresh-mechanical - mass transport- microstructure) and it is a need to recognize the optimum $\%$ blending of white cement with SRPC.

\section{Experimental program 2.1 Materials}

Two Types of cement, Sulphate resistance Portland cement and white cement used in this investigation were delivered from "Beni- suef cement company", Type CEMI $42.5 \mathrm{~N}$. 
Testing of cement was carried out per the Egyptian Standard Specifications ESS2421/2005 (14). The chemical and physical analysis of these cements is presented in Table 1. Natural siliceous sand with fineness modulus 2.73 was used as a fine aggregate. Dolomite with $10 \mathrm{~mm}$ M.N.S was used as a coarse aggregate, the physical properties of dolomite is presented in Table 2. Silica fume was delivered from Edfo city, Egypt. Tap water used for mixing and curing.

TABLE [1] Chemical and physical analysis of cement types.

\begin{tabular}{|c|c|c|}
\hline $\begin{array}{c}\text { Property } \\
\text { Chemical } \\
\text { composition, \% }\end{array}$ & SRPC & White cement \\
\hline $\mathrm{SiO}_{2}$ & 20.42 & 23.4 \\
\hline $\mathrm{Al}_{2} \mathrm{O}_{3}$ & 3.79 & 5.2 \\
\hline $\mathrm{Fe}_{2} \mathrm{O}_{3}$ & 4.49 & 0.25 \\
\hline $\mathrm{CaO}$ & 63.31 & 65.8 \\
\hline $\mathrm{MgO}$ & 1.88 & 0.5 \\
\hline $\mathrm{Na}_{2} \mathrm{O}$ & 0.36 & 0.1 \\
\hline $\mathrm{K}_{2} \mathrm{O}$ & 0.19 & 0.5 \\
\hline $\mathrm{SO}_{3}$ & 2.37 & 2.2 \\
\hline Bouge compounds, $\%$ & & 48.4 \\
\hline $\mathrm{C}_{3} \mathrm{~S}$ & 63.84 & 30.86 \\
\hline $\mathrm{C}_{2} \mathrm{~S}$ & 8.64 & 13.4 \\
\hline $\mathrm{C}_{3} \mathrm{~A}$ & 2.46 & 0.76 \\
\hline $\mathrm{C}_{4} \mathrm{AF}$ & 13.65 & 90 \\
\hline Initial setting time, min. & 135 & 255 \\
\hline Final setting time, min. & 300 & 430 \\
\hline Specific surface, ${ }^{2} / \mathrm{kg}$ & 360 & \\
\hline & & \\
\hline
\end{tabular}

TABLE 2 Physical properties of dolomite.

\begin{tabular}{|c|c|c|}
\hline $\begin{array}{c}\text { 24-hour water } \\
\text { absorption ,\% }\end{array}$ & Specific gravity & $\begin{array}{c}\text { Unit weight Kg/ } \\
\mathbf{m}^{\mathbf{3}}\end{array}$ \\
\hline 0.98 & 2.65 & 1665 \\
\hline
\end{tabular}

\subsection{Mixture proportions}

Fourteen mixtures were tested in this research made with percentage of white cement to $\mathrm{SRPC}=0,10,20,30,40,50$ and $100 \%$.Dolomite of $10 \mathrm{~mm}$ M.N.S mixed with cement, sand and water, the mix was $400 \mathrm{Kg}$ cement, $1200 \mathrm{Kg}$ dolomite, $10 \% \mathrm{~S} . \mathrm{F}$ as a partial replacement of cement and $600 \mathrm{Kg}$ sand per cubic meter of concrete at $\mathrm{w} / \mathrm{c}=0.50$. These constituents of concrete were mixed in mixer for two minutes, and then placed in cube moulds $10 \times 10 \times 10 \mathrm{~cm}$ for Isat, sorpitivity and compressive strength testing, whereas, the specimens for splitting tensile testing were cylinders $10 \times 20 \mathrm{~cm}$. cylindrical specimens $5 \mathrm{~cm}$ diameter and $0.50 \mathrm{~cm}$ height were used for thermo-gravimetric analysis (TGA). Table 3 presents the masses of materials used $\left(\mathrm{kg} / \mathrm{m}^{3}\right)$ and the corresponding costs per $\mathrm{m}^{3}$ for each of the mixtures.
Table[ 3] Composition of the concrete mixtures $\left(\mathrm{Kg} / \mathrm{m}^{3}\right)$ at $\mathrm{w} / \mathrm{c}=0.50$ and costs per $\mathrm{m}^{3}$ of concrete.

\begin{tabular}{|c|c|c|c|c|c|c|}
\hline Mix code & $\begin{array}{l}\text { White } \\
\text { cement }\end{array}$ & SRPC & Sand & Dolomite & S.F & $\begin{array}{l}\text { Cost } \\
\text { L.E }\end{array}$ \\
\hline W-0 & 0 & 400 & 600 & 1200 & - & 360 \\
\hline $\mathrm{W}-10$ & 40 & 360 & 600 & 1200 & - & 380 \\
\hline W-20 & 80 & 320 & 600 & 1200 & - & 400 \\
\hline W-30 & 120 & 280 & 600 & 1200 & - & 425 \\
\hline $\mathrm{W}-40$ & 160 & 240 & 600 & 1200 & - & 450 \\
\hline W-50 & 200 & 200 & 600 & 1200 & -- & 465 \\
\hline W-100 & 400 & 0 & 600 & 1200 & - & 555 \\
\hline $\mathrm{W}_{\mathrm{S}^{-}-0}$ & 0 & 360 & 600 & 1200 & 40 & 370 \\
\hline $\mathrm{W}_{\mathrm{S}^{-}}-10$ & 36 & 324 & 600 & 1200 & 40 & 390 \\
\hline $\mathrm{W}_{\mathrm{s}}-20$ & 72 & 288 & 600 & 1200 & 40 & 410 \\
\hline $\mathrm{W}_{\mathrm{S}^{-}} 30$ & 108 & 252 & 600 & 1200 & 40 & 435 \\
\hline $\mathrm{W}_{\mathrm{S}}-40$ & 144 & 216 & 600 & 1200 & 40 & 460 \\
\hline $\mathrm{W}_{\mathrm{S}-50}$ & 180 & 180 & 600 & 1200 & 40 & 475 \\
\hline $\mathrm{W}_{\mathrm{s}-100}$ & 360 & 0 & 600 & 1200 & 40 & 565 \\
\hline
\end{tabular}

\subsection{Testing}

In this research work, slump test carried as workability, whereas, the following tests on hardened concrete were carried out:

(a) Compressive strength: The compressive strength test was carried out according to the Egyptian Standard Specifications ESS 1658/2006( 15 ).To evaluate concrete compressive strength at test ages of 7 and 28 days.

(b) Splitting tensile strength: The splitting tensile strength test was carried out at 28 days age according to the Egyptian Standard Specifications ESS1658/2006(15).

(c) Initial surface absorption test ( Isat): At age of testing ( 28 days ), the tested cubes were oven dried at $105^{\circ} \mathrm{C}$ until reaching constant weight. Then, the dried specimens were left in a closed container for 24 hours until full stabilization. To avoid the effect of moisture, silica gel was put in small pots in the same container beside the specimens. The test period ( 2 hours), this test was carried out according to BS 1881: part 208-1996(16).

( d) Sorptivity test: The specimen preparation was carried out as the same of Isat, the test was carried out using a plastic container filled with water to a depth $20 \mathrm{~mm}$.Steel bars of $16 \mathrm{~mm}$ diameter were rested on the bottom of the container such that, the water was just above the top surface of the steel bars.The specimens were weighted using digital electric balance of $0.05 \mathrm{gm}$ accuracy. All surfaces around the chosen surface were then greased to about $2 \mathrm{~cm}$.The weights of the specimens were measured after removing the 
surface water at periods of 15 minutes up to 2 hours. The total amount of water absorbed was then monitored .The sorptivity of the tested specimens was calculated using the following equation (17):

$$
\mathrm{i}=\mathrm{A}+\mathrm{s} \mathrm{t}^{0.5} \text {....................... }
$$

$\mathrm{A}$, is constant,

$\mathrm{i}$, is the increase in mass in $\mathrm{g} / \mathrm{mm}^{2}$,

$\mathrm{t}$, is the time, measured at which the weight is determined,

$\mathrm{S}$, is the sorptivity in $\mathrm{mm} / \mathrm{sec}^{0.5}$

(e) Thermo-gravimetric analysis (TGA): TGA was carried out on cylindrical cement paste specimens $(50 \mathrm{~mm}$ diameter and $5 \mathrm{~mm}$ height), with different replacement of white cement to OPC to determine the amount of hydration product in cement mixes. These specimens were cast in PVC mould and after the end of curing period (28) days, the specimens were weighted in saturated surface dry (SSD) condition, and then the specimens were put in an electric with surface temperature up to $1200^{\circ} \mathrm{C}$. The weight of specimens were recorded at various temperatures $(105,250,450,600,700,900$ and 950), then the weight loss resulted from the decomposition of matrix were used for calculation their different phases of hydration products. This method was followed by (18) and (19) ,where C-S-H decomposes at range $105-250^{\circ}, \mathrm{C}-\mathrm{H}$ decomposes at range of 450-600, all non evaporable water(NEW), bound water release at $950^{\circ} \mathrm{C}$. The test specimen, age of testing and standard are presented in Table 4.

TABLE [ 4] The test specimens and age of testing

\begin{tabular}{|c|c|c|}
\hline Test & $\begin{array}{c}\text { Test } \\
\text { specimen }\end{array}$ & $\begin{array}{c}\text { Age of } \\
\text { testing }\end{array}$ \\
\hline $\begin{array}{c}\text { Compressive } \\
\text { strength }\end{array}$ & $\begin{array}{c}100 \mathrm{~mm} \\
\text { cube }\end{array}$ & $\begin{array}{c}7 \text { and } \\
28 \text { days }\end{array}$ \\
\hline $\begin{array}{c}\text { Splitting tensile } \\
\text { strength }\end{array}$ & $\begin{array}{c}\text { Cylinder } \\
\text { of } 100 \mathrm{~mm} \\
\text { diameter and } \\
200 \mathrm{~mm} \text { length }\end{array}$ & 28 days \\
\hline Isat & $\begin{array}{c}100 \mathrm{~mm} \\
\text { cube }\end{array}$ & 28 days \\
\hline Sorptivity & $\begin{array}{c}100 \mathrm{~mm} \\
\text { cube }\end{array}$ & 28 days \\
\hline TGA & $\begin{array}{c}5 \mathrm{~cm} \\
\text { diameter, } 0.5 \mathrm{~cm} \\
\text { thickness }\end{array}$ & \\
\hline
\end{tabular}

\section{Test results and discussions}

\subsection{Slump}

The effect of $\%$ blending of white cement with SRPC on slump is presented in "Fig. 1" .It is apparent from this Figure that, $30 \%$ percentage of white cement to SRPC exhibit highest slump whereas, the lowest value of slump observed at $100 \%$ white cement, generally up to $30 \%$ blending white cement with SRPC increased the slump, after this percentage the slump start to decrease. This result is contrary to the result obtained by (5) and (6) that reported that white cement led to increasing the slump compared to OPC.

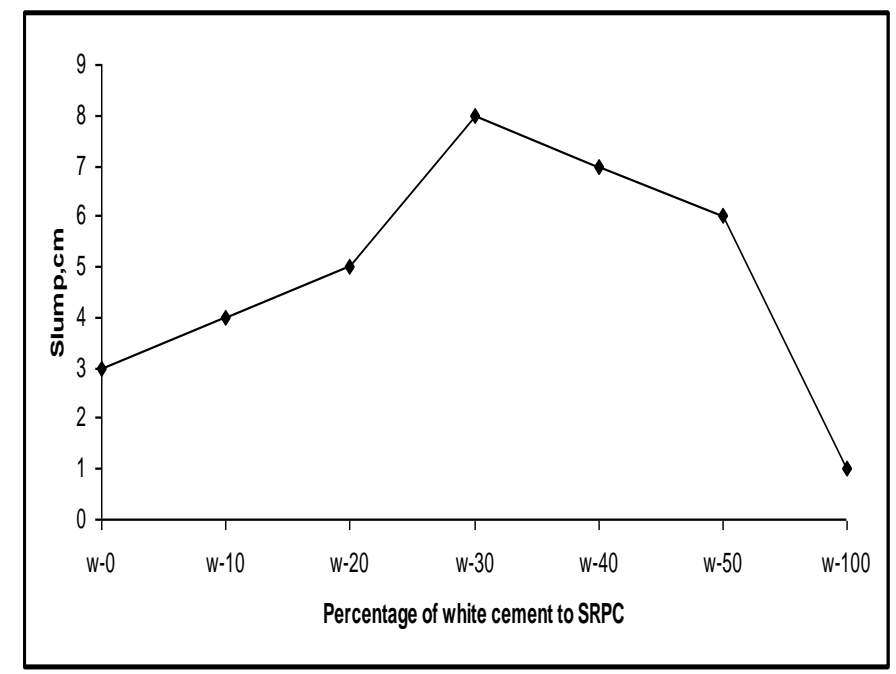
slump.

Figure 1. Effect of percentage of white cement to SRPC on concrete

\section{2Hydration of Cement}

Table 5 represents the impact of percentage of white cement to SRPC on hydration products of cement, it is apparent that the maximum decomposition of weight due to C-S-H observed at $20 \%$ percentage of white cement to OPC, whereas, the maximum decomposition of weight due to $\mathrm{C}-\mathrm{H}$ obtained at $30 \%$ percentage of white cement to SRPC. At $50 \%$ blending of white cement with SRPC exhibit maximum NEW, otherwise, minimum NEW is observed at $100 \%$ white cement.

TABLE[5] Decompositions due to C-S-H, C-H and NEW, bound water,\% for different mixes.

\begin{tabular}{|c|c|c|c|}
\hline Code mix. & $\begin{array}{c}\text { Weight loss due to } \\
\text { decomposition of } \\
\text { C-S-H,\% }\end{array}$ & $\begin{array}{c}\text { Weight loss due to } \\
\text { Decomposition of } \\
\text { C-H, \% }\end{array}$ & wEW, bound \\
water, \% \\
\hline W-0 & 8 & 6.1 & 30.7 \\
\hline W-10 & 6.8 & 7.7 & 30.9 \\
\hline W-20 & 8.7 & 5 & 31.8 \\
\hline W-30 & 5 & 8.7 & 32 \\
\hline W-40 & 6.2 & 8.1 & 32.8 \\
\hline W-50 & 6.3 & 7.8 & 29.5 \\
\hline W-100 & 6.9 & 6.1 & \\
\hline
\end{tabular}

\subsection{Mass transport properties \\ 3.3.1 Initial surface absorption test}

The influence of percentage of white cement to SRPC on flow rate by Isat is presented in "Fig.2" , it is observed from this Figure that, compared to grey cement white cement increased the flow rate, whereas, $30 \%$ percentage of white cement to SRPC exhibit lowest value of flow rate. 


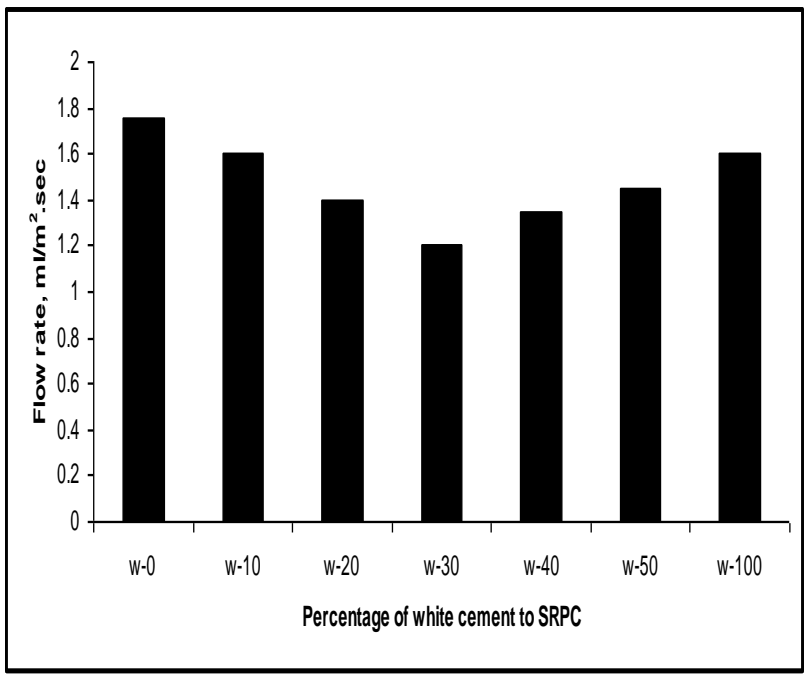

Figure 2.Effect of percentage of white cement to SRPC on flow rate of concrete.

\subsubsection{Sorptivity}

The effect of percentage of white cement to SRPC on sorptivity of concrete containing its is presented in" Fig. 3", it is observed from this Figure that, compared to grey cement, white cement increased the sorptivity, whereas, $30 \%$ percentage of white cement to SRPC exhibit lowest value of sorptivity.

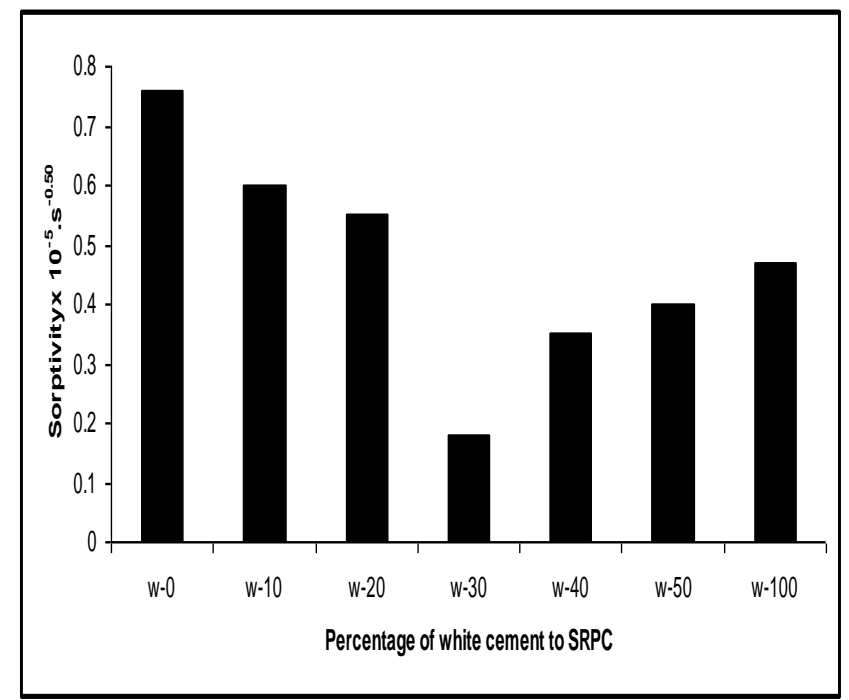

Figure 3.Effect of percentage of white cement to SRPC on sorptivity of concrete.

\subsection{Compressive strength}

"Figs . 4, 5" represent the impact of percentage of white cement to SRPC on compressive strength, it is apparent from these Figures, that increasing the age, the compressive strength of concrete containing various percentage of white cement to SRPC developed, compared to grey cement neat white cement increased the compressive strength by $8 \%$, this result is agree with the result obtained by Lubeck et al (7).The maximum compressive strength is observed at $30 \%$ percentage of white cement to SRPC , this result may be attributed to the lowest values of flow rate and sorptivity observed at $30 \%$ percentage of white cement to SRPC. Also, this result agrees with the result obtained by TGA, where the maximum $\mathrm{C}$ - $\mathrm{H}$ observed at $30 \%$ percentage of white cement to SRPC. Compared to grey cement,10\% S.F increased the concrete compressive strength, whereas, introducing S.F in white cement mixes led to decreasing the concrete compressive strength, especially above $20 \%$ white cement to SRPC .This result may be attributed to the lower $\mathrm{c} 4 \mathrm{AF}$ in white cement.

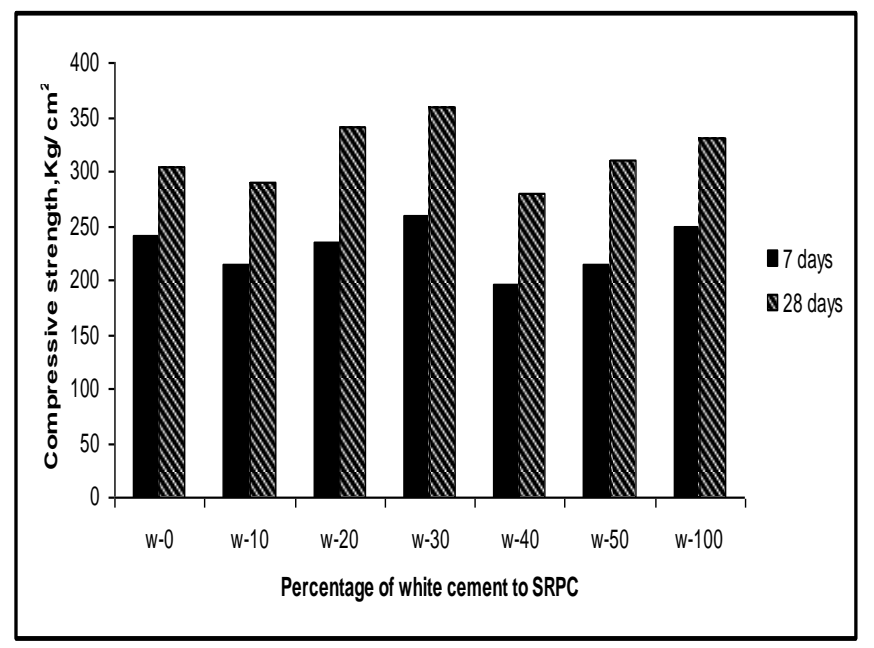

Figure4. Influence of percentage of white cement to SRPC on concrete compressive strength at various ages.

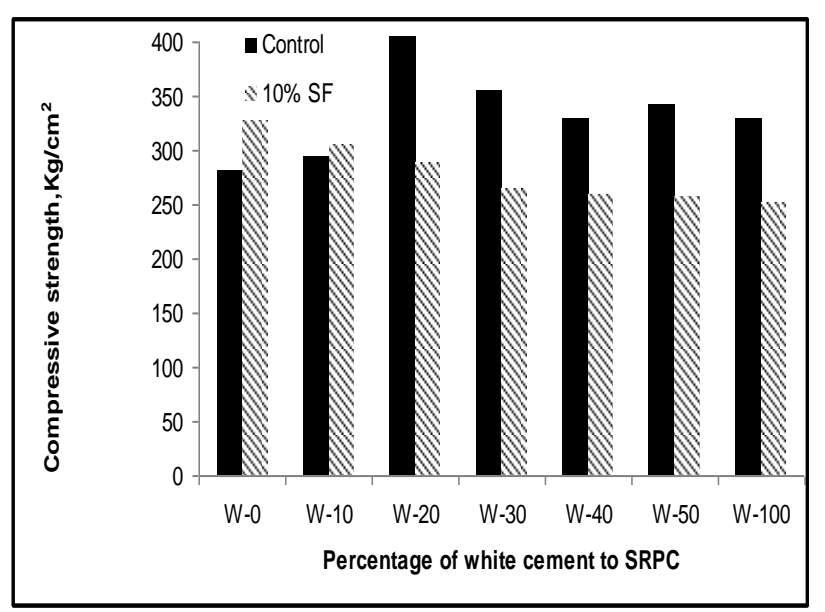

Figure 5.Effect of SF on compressive strength of concrete containing various percentage of white cement to SRPC at 28 days.

\subsection{Splitting tensile strength}

"Fig. 6" represents the impact of \% blending of white cement with SRPC on splitting tensile strength, it is apparent from this Figure, that the peak splitting tensile strength is exhibited at $30 \%$ percentage of white cement to SRPC, this result agree with the results obtained by Isat and sorptivity where lowest values of flow rate and sorptivity observed at $30 \%$ percentage of white cement to OPC. Also, this result agrees with the result obtained by TGA, where the maximum $\mathrm{C}-\mathrm{H}$ observed at $30 \%$ percentage of white cement to SRPC. The splitting tensile strength of gray cement was greater than that of white cement, these results agree with the result obtained by (6). 


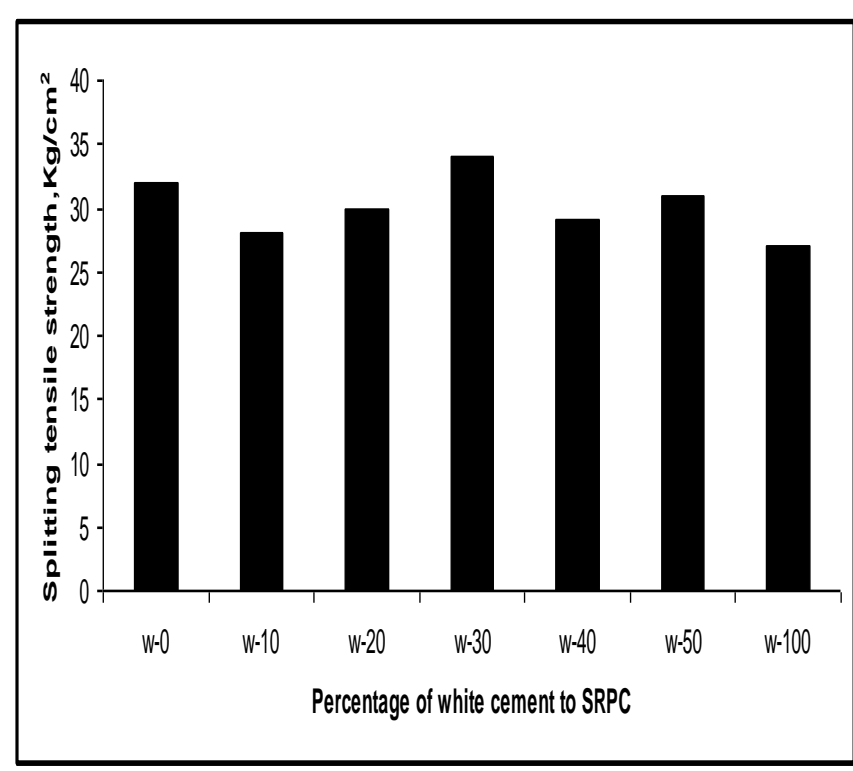

Figure6. Influence of percentage of white cement to SRPC on concrete splitting tensile strength at 28 days.

\section{Conclusions}

Based on this experimental study, the following conclusions can be drawn:

1-Percentage of white cement to SRPC up to $30 \%$ led to enhancing the slump however, at percentage above $30 \%$ the slump starts to decrease, and for neat white cement mix, the slump is lower than that of neat SRPC concrete.

2- $30 \%$ percentage of white cement to SRPC increased C- $\mathrm{H}$ to maximum value.

3- Compared to different $\%$ percentage of white cement to SRPC, $30 \%$ white cement to SRPC decreased the flow rate and sorptivity to lowest values.

4-Percentage of white cement to SRPC enhanced the compressive strength, the maximum compressive strength observed at $30 \%$ white cement.

5-Introducing S.F in concrete containing \% white cement to SRPC above $20 \%$ led to decreasing the concrete compressive strength.

6- The maximum splitting tensile strength occurred at $30 \%$ percentage of white cement to SRPC.

\section{Refrences}

[1] S.H., Kozmatka, W.C.,Panarese, "Design and Control of Concrete Mixtures; Portland Cement

Association":Skokie,IL, 1988.

[2] D.F. Orchard, "Concrete Technology", Vol.1,John

Wiley,Sons:New York,1962.

[3] S.,Mindess ,J.F.Young," Concrete";Prentice Hall:EngleWood Cliffs,NJ,1981.

[4] C., Xibi, W.,Zhaogi, "The Production and application of special cement",326, Architectural Publishing Company.
[5] S.,Chandra, J.,Bjornstrrom, "Influence of cement and superplasticizers type and dosage on the fluidity of cement mortars-PartI",Cement and Concrete

Research,Vol.32,pp.1605-1611,2002.

[6] B.S,Hamad, "Investigations of chemical and physical properties of white cement concrete",Advanced Cement Based Materials,Vol.2,pp.161-167, 1995.

[7] A., Lubeck, D.S., Gastaldini Barin , H.C .,Siqueira," Compressive strength and electrical properties of concrete with white Portland cement and blast furnace slag", Cement and Concrete Composite, Vol.34,pp.392-399,2012.

[8] P.A.M, Basheer, P.R.V Gillece, , A.E, Long

W.J.McCarter,"Monitoring electrical resistance of concretes containing alternative cementitious materials to assess their resistance to chloride penetration".Cement and Concrete Composite,Vol.24, pp.437-449,2002.

[9] J.,Khatib ,JJ. ,Hibberet "Selected engineering properties of concrete incorporating slag and metakaoline",Concrete and Building Materials, Vol.19,pp.460-472,2005.

[10] K.Y., Yeau, E.K, Kim,"An experimental study on corrosion resistance of concrete with ground granulate blastfurnace slag",Cement and Concrete Composite,Vol.35, pp.1391-1399,2005.

[11] A.E., Oner, S., Akyuz,"An experimental study on optimum usage of GGBS for the compressive strength of concrete", Cement and Concrete Composite, Vol. 29, pp.505$514,2007$.

[12] V., Petkova, V., Stoyanov., and Y., Pelovski, "TGDTG-DTA in studying white self-compacting cement mortars" ,Journal Therm Anal Calorim,Vol.109,pp.797806,2012.

[13] IJ., Escalante-Garcia, JH Sharp," Effect of temperature on the hydration of the main clinker phases in Portland cements: part I, Cement and Concrete Research, Vol.28,pp.1245-1257,1998.

[14] ESS 2421/2005-Egyptian standard specification, cement-physical and mechanical testing.

[15] ESS 1658/2006- Egyptian standard specification, testing of concrete.

[16] B.S 1881: part 208-1996-Testing concrete-

Recommendations for the determination of the initial surface absorption of concrete.

[17] C., Hall, "Water sorptivity of mortars and concrete: a review, Magazine of Concrete Research, Vol.41,issue 147,pp.51-61,1989.

[18] A.A , Rahman, F.P., Glasser , " Comparative studies of the carbonation of hydrated cements", Advanced in Concrete Research,Vol.2,No.6,pp.49-54,1989.

[19] G.E, Abdelaziz, " Microstructural analysis of surface and interface zones in concrete" ,ph.D.Thesis,Aston University,UK,250 pp,1998. 